\title{
Facts about Zinc ${ }^{1}$
}

Linda B. Bobroff ${ }^{2}$

\section{Why do we need zinc?}

Zinc is a mineral that is found in almost every cell in our bodies. It's needed for hundreds of chemical reactions. Zinc helps with:

(:) Keeping our immune system healthy

(i) Use of vitamin A in the body

(;) Normal cell replacement

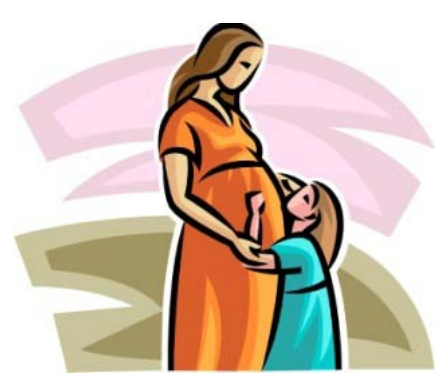

Zinc is needed for optimal growth and development. It is critical for pregnant women and children to get enough zinc in their diets.

\section{How much zinc do we need?}

The recommended daily intakes of zinc for most adults are as follows:

\begin{tabular}{|l|c|}
\hline \multicolumn{1}{|c|}{ Life Stage } & $\begin{array}{c}\text { Amount } \\
\text { (mg/day) }\end{array}$ \\
\hline Men, ages 19+ & 11 \\
\hline Women, ages 19+ & 8 \\
\hline Pregnancy* & 11 \\
\hline Breastfeeding** & 12 \\
\hline $\begin{array}{l}\text { *Pregnant teens need } 12 \mathrm{mg} \\
\text { **Breastfeeding teens need 13 mg } \\
\text { mg = milligrams of zinc }\end{array}$ \\
\hline
\end{tabular}

\section{How can we get enough zinc?}

The best food sources of zinc are seafood, meat, poultry, beans, nuts and some fortified cereals. The zinc found in animal foods is easily absorbed by the body. Whole grains also contain zinc, but it is not

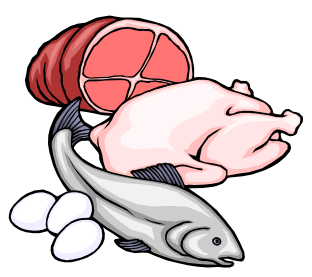
well absorbed.

1. This document is FCS8705, one of a s eries of the Department of Family, Y outh and Community S ciences, F lorida Cooperative Extension S ervice, Institute of Food and Agricultural Sciences, University of Florida. First published: June 2001. Revised: January 2006; June 2009.

2. Linda B. Bobroff, PhD, RD, LD/N, professor; Department of Family, Y outh and Community Sciences; Cooperative Extension Service; Institute of Food and Agricultural Sciences; University of Florida; Gainesville, FL 32611. 
Here are some foods and the amount of zinc they contain:

\begin{tabular}{|l|c|}
\hline \multicolumn{1}{|c|}{ FOOD } & $\begin{array}{c}\text { ZINC } \\
\text { (mg/serving) }\end{array}$ \\
\hline Oysters, cooked, 3 oz & 75 \\
\hline Crab meat, cooked, 3 oz & 7 \\
\hline $\begin{array}{l}\text { Beef chuck, lean, } \\
\text { cooked, 3 oz }\end{array}$ & 7 \\
\hline Fortified cereals, 1 cup & $3-4$ \\
\hline Chicken leg, cooked, 3 oz & 3.6 \\
\hline $\begin{array}{l}\text { Hamburger (fast food), } \\
\text { small }\end{array}$ & 2 \\
\hline $\begin{array}{l}\text { Baked beans, canned, } \\
\text { /2 cup }\end{array}$ & 1.2 \\
\hline Pecans, chopped, 1/4 cup & 1 \\
\hline Milk, 1 cup & \\
\hline $\begin{array}{l}\text { mg = milligrams } \\
\text { oz = ounces }\end{array}$ & \\
\hline
\end{tabular}

\section{What about supplements?}

Multivitamin supplements with minerals usually contain zinc. These supplements can be used by people who may not get enough

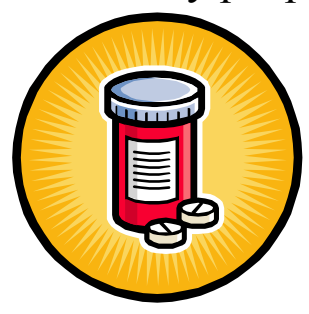
zinc in their diets. People 51 years of age and older, pregnant women, and nursing moms may benefit from taking a supplement containing zinc.
Many people believe that taking zinc lozenges decreases the duration of colds. However, most studies have not found that zinc lozenges are helpful. This is an area that needs more research.

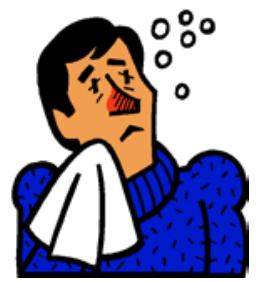

\section{How much is too much?}

High intakes of zinc can be toxic. Large amounts of zinc also can interfere with absorption of other minerals. You should not get more than $40 \mathrm{mg}$ of zinc a day, from food and supplements together.

\section{Where can I get more information?}

The Family and Consumer Sciences (FCS) agent at your local Extension office may have written information and nutrition classes for you to attend. Also, your doctor or a registered dietitian $(\mathrm{RD})$ can provide you with reliable information.

Reliable nutrition information may be found on the Internet at the following sites:

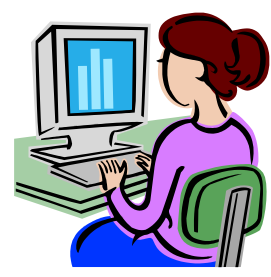

http://solutionsforyourlife.ufl.edu http://www.nutrition.gov http://www.ars.usda.gov http://ods.od.nih.gov/factsheets/Zinc_pf.asp 